\title{
Effect of AMF Inoculation on the Growth of Combretocarpus rotundatus (Miq) on a Peat Soil from Central Kalimantan (For Restoration Ex-Mega Rice Project Central Kalimantan)
} \author{
Pemulihan Lahan Ex-PLG Kalimantan Tengah) \\ Burhanuddin $^{1}$, Siti Kabirun ${ }^{2}$, Bostang Radjagukguk ${ }^{2}$, dan Sumardi ${ }^{3}$ \\ ${ }^{1}$ Doctoral student in Soil Science, Faculty of Agriculture, Gadjah Mada University \\ ${ }^{2}$ Faculty of Agriculture, Gadjah Mada, University, Yogyakarta, Indonesia \\ ${ }^{3}$ Faculty of Forestry, Gadjah Mada, University, Yogyakarta, Indonesia \\ E-mail: hans_borneo@yahoo.co.id *Penulis untuk korespondensi
}

Pengaruh Inokulasi Jamur Mikoriza Arbuskula (JMA) pada Pertumbuhan Perepat (Combretocarpus rotundatus (Miq) di Tanah Gambut Kalimantan Tengah (Untuk

\begin{abstract}
Abstrak
Diperlukan teknik silvikultur dengan memanfaatkan jamur mikoriza arbuskula (JMA) untuk memulihkan hutan rawa gambut yang terdegradasi. JMA berperan penting pada pertumbuhan dan ketahanan hidup pohon-pohonan. Penelitian ini bertujuan untuk mengetahui keberadaan dan bentuk dari JMA di hutan rawa gambut yang sudah terdegradasi pada blok $\mathrm{C}$ bekas pengembangan lahan gambut satu juta ha di Kelampangan Kalimantan Tengah. Kondisi lahan hanya ditumbuhi vegetasi jenis-jenis pioner. Contoh tanah diambil dibawah perakaran lima jenis tanaman pioner (Melastoma sp, Combretocarpus sp, Acacia sp, Cratoxylon sp, dan Nephrolepsis sp), kemudian contoh tanah dihitung jumlah spora dengan metode saringan basah. Jumlah spora terbanyak ada di bawah perakaran tanaman Melastoma sp, kemudian Acacia sp, dan Combretocarpus sp. Didapatkan tiga genus JMA: Glomus, Gigaspora, dan Acaulospora. Penelitian di rumah kaca bertujuan untuk mengetahui pengaruh inokulasi JMA jenis Glomus sp TD15, Glomus sp D32, dan Gigaspora sp pada semai perepat (C. rotundatus). Hasil penelitian menunjukkan JMA memberikan pengaruh pada parameter semai yang diukur. Jenis JMA Glomus sp TD15 meningkatkan pertumbuhan semai perepat yang ditunjukkan oleh parameter tinggi semai, diameter semai, dan jumlah daun per tanaman. Pada media gambut semai $C$. rotundatus sangat tergantung pada asosiasi JMA dalam meningkatkan pertumbuhan tanaman.
\end{abstract}

Kata kunci: Peat-swamp forest, ex-MRP

\section{Abstract}

For the restoration of degraded peat swamp forest, silvicultural techniques using Vesicular Arbuscular Mycorrhizal (VAM) are considered necessary. VAM fungi symbiotic relationships play an important role for the growth and survival of trees. The objective of this study is to observe the VAM fungal status of a typical peat swamp forest in Block C ex-MRP at Kelampangan in Central Kalimantan which has been cleared and disturbed. Currently the site is occupied by various pioneer plants. Soil samples from the rhizosphere of five pioneer vegetation (Melastoma sp, Combretocarpus sp, Acacia sp, Cratoxylon sp, and Nephrolepsis sp) were collected and spores were isolated from the soil using a wet sieving and decanting method. Greatest spore number was observed in the rhizosphere of Melastoma sp, followed by Acacia sp, and Combretocarpus sp. Three genera of VAM fungi were found, namely Glomus, Gigaspora, and Acaulospora. A field experiment was conducted to examine the effect of the arbuscular vesicular mycorrhizal fungus Glomus sp TD15, Glomus sp D32 and Gigaspora sp and seedling on the growth of Combretocarpus rotundatus (Miq). In general the VAM fungi used in this study showed benefical effect on plant growth parameters. The colonization by Glomus sp TD15 produced the highest plant height, stem diameter and leaf number per plant. On the peat soil medium, Combretocarpus rotundatus (Miq) showed a high degree of dependence on mycorrhizal association, increasing with the age of the plants.

Key words: Peat-swamp forest, ex-MRP 


\section{Introduction}

Tropical peatlands make up approximately $12 \%$ (30-45Mha) of the total global peatlands (Immirizi and Maltby, 1992), of which Indonesia supports the greatest area, 20 Mha (Radjagukguk, 2001). In the last decade large areas of the Indonesian peatlands have experienced serious damage as a result of human activities such as logging and drainage. Peatland site development is often associated with the construction of drainage canals in order to make the land usable for agriculture or, more often, for oil palm and pulp wood plantations. Canals and ditches are not only built to control and lower the water level but also to facilitate access to the peat swamp forest and for transportation of timber logs (Jaenicke and Siegert, 2008). After forest clearance, peat becomes more susceptible to fires and flooding, resulting in a downward cycle of retro-succession, with floral diversity becoming dominated by shrubs, ferns and sedge (Page et al., 2008). When undisturbed, peatlands play an important role in the global carbon (C) cycle, storing about $450 \mathrm{Gt} \mathrm{C}$, which the amount is about $30 \%$ of the global soil carbon pool (Gorham, 1991), and peatlands act as carbon sinks (Page et al., 2002), support extremely high levels of floral and faunal biodiversity (Cheyne et al., 2007), maintain stable hydrological and nutrient cycling systems (Wösten et al., 2006) and provide means of livelihood for local communities (Smith, 2002).

The Indonesian Government has a national program to accelerate rehabilitation of degraded peat swamp forest. Peat soil has an extremely low $\mathrm{pH}$ and revegetation of the peat soil is difficult because of the high concentration of toxic elements, such as aluminum, and poor nutrient availability. However, it is not easy to rehabilitate this ecosystem immediately, because it is necessary to select and produce high quality tree seedling species for rehabilitation. In order to implement successful rehabilitation programs, transferable methods need to be developed. This paper considers the use of mycorrhizae inoculation for seedling transplants as one of these potential methods.

Mycorrhizae are fungi that form symbiotic relationships with plant roots. The two most common forms of mycorrhizae are ectomycorrizae and arbuscular mycorrhizae fungi (AMF). In exchange for sugars produced by the plant, the mycorrhizae provide additional phosphates, nitrates, and other micro and macronutrients, can increase water supply through times of drought, and reduce susceptibility to soil-borne pathogens (Dell, 2002). Mycorrhizae play a crucial role in ecosystem processes, including plant and soil community composition and ecosystem resource capture (Rillig, 2004).

Studies in the tropics, of the relations between mycorrhizae, their plant hosts and their ecosystems have been under studied in relation to the temperate zone, though in recent years this has begun to be remedied (for example, Kiers et al., 2000; Lovelock and Ewel, 2005; Tawaraya et al., 2003). These studies have shown mycorrhizae are just as important in tropical as in temperate biomes. Tawaraya et al., (2003) established that in TPSF 17 of 23 Dipterocarp species hosted both AMF and ectomycorrhizae. Equally, once the correct mycorrhizal species was established for a given host species, the symbiosis was shown to increase plant biomass, height, leaf production and nutrient assimilation, under nursery conditions (Turjaman et al., 2005; Turjaman et al., 2006).

Arbuscular Mycorrhizal Fungi (AMF) are symbiotic associations, formed between plants and soil fungi that has essential role in plant growth, plant protection, and soil quality that benefit both partners. The phytobiont correspond to approximately $80 \%$ of plant species and the fungi are classified in the phylum Glomeromycota, including nine genera; Glomus, Paraglomus, Acaulospora, Entrophospora, Gigaspora, Scutellospora, and Archaeospora (Dalpe, 2004).

The symbiotic relationship between AMF and the roots of higher plants contributes significantly to plant nutrition and growth (Auge, 2001; Amaya-Carpio et al., 2009). These positive responses in productivity to AMF colonization have mainly been attributed to the enhanced uptake by AMF of relatively immobile soil ions such as phosphorus, potassium, calcium, magnesium, sulfur, iron, zinc, copper, and manganese (Marschner et al., 1994; Liu et al., 2007), but also involve the enhanced uptake and transport of far more mobile nitrogen ions, 
particularly under drought conditions (Liu et al., 2007). Enhanced plant growth might also result from soil-borne pathogen (e.g. nemathodes, pathogenic fungi, bacteria) protection (Cardoso and Kuyper, 2006; St-Arnaud and Vujanovic, 2007), improved soil structural development and aggregate stabilization (Miller and Jastrow, 2000; Picone, 2003; Rillig, 2004; Wright, 2005).

AMF symbiosis, a natural association between the roots of higher plants and arbuscular mycorrhizal, are important in trees, because AMF are believed to improve host plants growth, water relations and acquisition of nutrients especially P from soil (Bucher, 2007). Mycorrhizas affect the maintenance of vegetation in various ecosystems, and may play an important role in tropical peat swamp forest. AMF may be formed even in trees, which grow in the peat swamp forest.

Combretocarpus rotundatus $\mathrm{Miq}$ is classified into fast-growing tree species and has tolerance to strong light, drought and high soil temperature condition in their regenerate and survivorship (Saito et al., 2002). This species is also an important timber tree in tropical peat swamp forest in Indonesia. C. rotundatus is distributed over scattered locations of Kalimantan and Sumatra islands, and attains height of up to $30 \mathrm{~m}$ and diameter of up to 60 $\mathrm{cm}$. This species is common and often gregarious in tropical peat swamp forest.

\section{Study Site}

Peatland of Central Kalimantan is distributed in the lowland area, about $5-35 \mathrm{~m}$ above sea level, and stretches approximately 200 $\mathrm{km}$ inland (Fig. 1). It holds nearly $27 \%$ of the total peatland on Kalimantan Island (Shimada, 2001). Some large rivers, such as the Kapuas, Barito, and Katingan, flow from the mountains of northern side of the peatlands through the peatlands to the Java Sea. Peat thickness varies among peatland types, from approximately 0.5 to $9.7 \mathrm{~m}$ (Shimada et al., 2001). Tropical peat swamp forest occupies most of the Central Kalimantan area. Part of the forest has been either cleared for cultivation and logging or destroyed by peatland fires. The study site is located in the Kelampangan forest. A large part of this forest has been degraded both by cultivation and human settlement and by the enormous forest and peat fires in 1997.

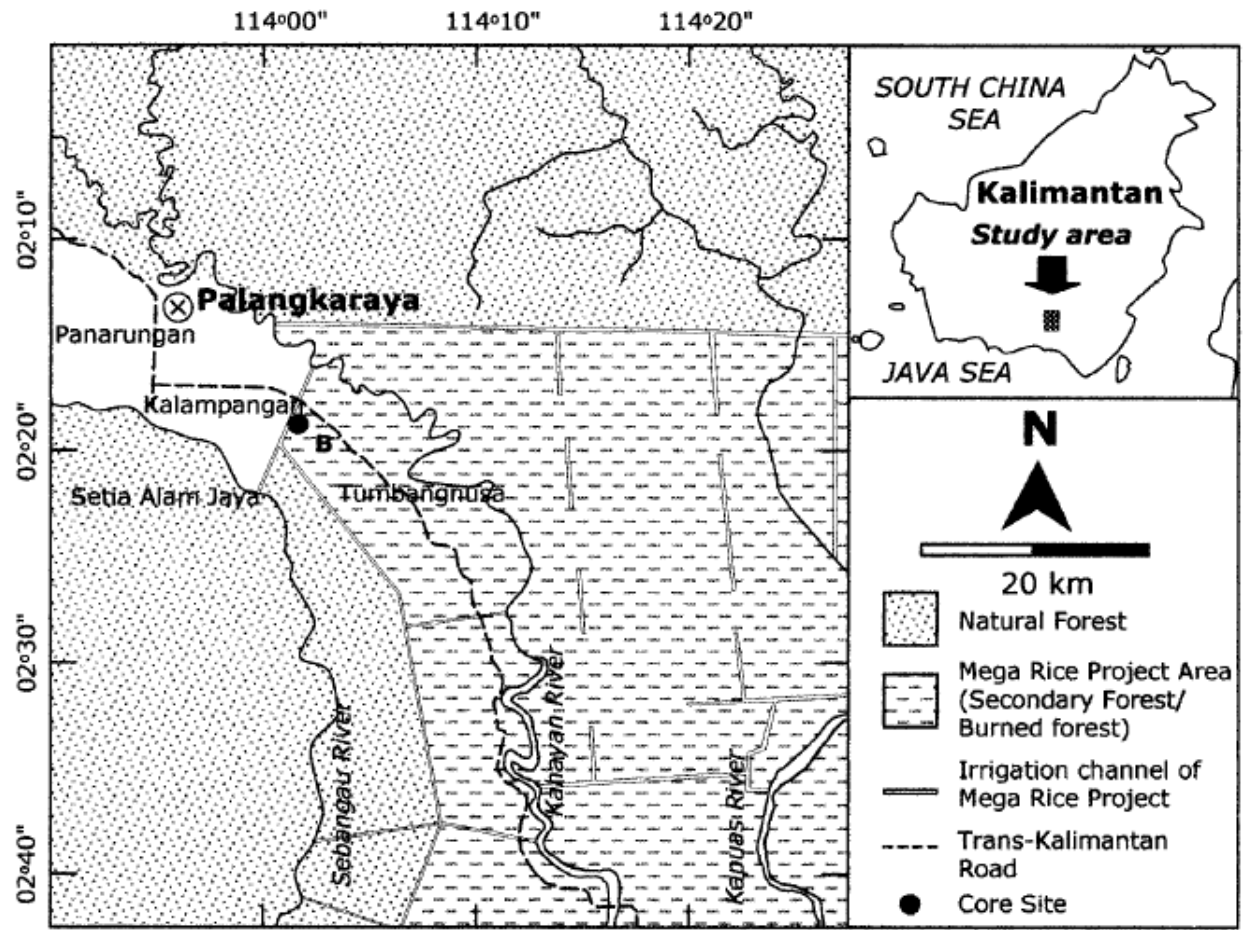

Figure 1. Map of the study site (after Yulianto et al., 2004). 


\section{Materials and Methods}

Isolates of VAM fungi were collected from rhizosphere of pioneer plants in Ex Block C Mega Rice Project (MRP) in Central Kalimantan (Fig. 1). Five different pioneer plants, namely Combretocarpus sp, Acacia sp, Melastoma sp, Cratoxylon sp, and Nephrolepsis sp were compared. Isolation and identification of AM fungal spore were conducted in the Laboratory of Microbiology, Faculty of Agriculture, Gadjah Mada University in Yogyakarta. The identification followed Manual for Identification of VAM fungi and examination was conducted under a dissecting microscope (Brundrett et al., 1996).

Seeds of C. rotundatus were the surface sterilized in $70 \%$ alcohol for $5 \mathrm{~min}$, subsequently rinsed with sterilized water and germinated on sterilized peat soils. Four week old uniform seedlings were transplanted into plastic pots (30 x $30 \mathrm{~cm})$ containing $2.0 \mathrm{~kg}$ autoclaved $(0.11$ $\mathrm{MPa}, 121^{\circ} \mathrm{C}, 2 \mathrm{~h}$ ) peat soil with a $\mathrm{pH}$ of 3.3 , and $5.91 \mathrm{mg} \mathrm{kg}^{-1}$ available phosphorus. The experimental pots were placed in a plastic greenhouse under natural light conditions from September, 2007 to January, 2008, which had no controlling temperature equipment. The average day/night temperature was $29 / 21^{\circ} \mathrm{C}$ and the relative humidity was $70-90 \%$.

The AMF used in this study were Glomus sp TD15, Glomus sp D32, and Gigaspora sp obtained from Block C ex-PLG Central Kalimantan. The inoculation with AMF was added as soil from pure pot cultures containing spores and mycorrhizal root fragments, $30 \mathrm{~g} / \mathrm{pot}$ of inoculum was placed directly below the seedlings. Non-AMF treatments (control seedlings) received the same weight of autoclaved growth media.

The experimental treatments were made up of three AMF inoculations (Glomus sp TD15, Glomus sp D32, Gigaspora sp, and non-AMF) under greenhouse nursery condition and were arranged in a completely randomized design. Each treatment had six replicates and, hence, there were a total of 24 pots with one seedling per pot.
Five months after planting, plant height, stem diameter and leaf number per plant were recorded and the AMF and non-AMF seedlings were harvested. All of the seedlings were separated into roots and shoots, dried in hot-air oven at $75^{\circ} \mathrm{C}$ for $2 \mathrm{~d}$, and dry weights of shoots and roots were recorded. Part of fresh roots was carefully washed, cut into $1 \mathrm{~cm}$ long root segments and fixed by FAA at least $24 \mathrm{~h}$. The root samples were cleared with $10 \% \mathrm{KOH}$ solution, stained with $0.05 \%$ trypan blue in lactophenol (Phillips and Hayman, 1970), and examined microscopically for root colonization. The AMF infected percentage was calculated by the following formula: AMF colonization $(\%)=$ $100 \mathrm{x}$ root length/root length observed (Smith and Read, 2008).

The experimental data were subjected to analysis of variance (ANOVA) with Statistical Analysis System (SAS) 8.1 software, and Fisher's Protected Least Significant Difference (LSD) $(\rho=0.05)$ was used to compare treatment means.

\section{Results and Discussion}

The results showed that AM fungi was abundant in rhizosphere of pioneer plants and identification to the spore revealed that there were three genera of AM fungi, namely Glomus, Gigaspora, and Acaulospora (Table 1 and Fig. 2, 3).

The greatest spore number was obtained in the rhizosphere of Melastoma sp (263 spores), followed by rhizosphere of Acacia (108 spores), and rhizosphere of Combretocarpus sp (68 spores). AM fungi are ubiquitously associated with the large majority of plant families in different ecosystems across the world ranging from the tropics to subtropics (Gai et al., 2006). Opik et al., (2006) suggested that the location effect on AM fungal communities might be significant through a meta-analysis of 26 publications that reported AM community compositions in different locations of the world. They also pointed out, however, that there were too few studies on fungal communities of the same plant species at different site. 
Burhanuddin et al.,

Table 1. Type and spore number of VAM fungi in the rhizosphere of pioneer plants.

\begin{tabular}{cccl}
\hline \hline No. & \multicolumn{1}{c}{ Plant } & Spore number per 100 g soil & \multicolumn{1}{c}{ AMF species } \\
\hline \hline 1. & Combretocarpus $\mathrm{sp}$ & 68 & Glomus sp;Acaulospora sp; Gigaspora sp \\
2. & Acacia $\mathrm{sp}$ & 108 & Glomus sp; Gigaspora $\mathrm{sp}$ \\
3. & Melastoma $\mathrm{sp}$ & 263 & Glomus sp;Acaulospora sp; Gigaspora $\mathrm{sp}$ \\
4. & Cratoxylon $\mathrm{sp}$ & 8 & Glomus sp;Acaulospora sp \\
5. & Nephrolepsis $\mathrm{sp}$ & 7 & Glomus $\mathrm{sp}$ \\
\hline \hline
\end{tabular}

Table 2. Plant growth and AMF colonization of $C$. rotundatus inoculated with three VAM types 5 months after transplanting under nursery conditions.

\begin{tabular}{|c|c|c|c|c|c|}
\hline \multirow[b]{2}{*}{ Treatment } & \multicolumn{4}{|c|}{ Plant growth } & \multirow{2}{*}{$\begin{array}{c}\mathrm{AM} \\
\text { Colonization }(\%)\end{array}$} \\
\hline & $\begin{array}{c}\text { Shoot Height } \\
(\mathrm{cm})\end{array}$ & $\begin{array}{c}\text { Stem Diameter } \\
(\mathbf{m m})\end{array}$ & $\begin{array}{c}\text { Leaf Number } \\
\text { per (plant) }\end{array}$ & $\begin{array}{c}\text { Dry Weight } \\
\text { (g/plant) }\end{array}$ & \\
\hline Control & $10.26 \mathrm{c}^{*}$ & $2.16 \mathrm{c}$ & $10 \mathrm{c}$ & $4.45 \mathrm{c}$ & $9 \mathrm{c}$ \\
\hline Glomus sp TD15 & $41.96 \mathrm{a}$ & $5.16 \mathrm{a}$ & $36 \mathrm{a}$ & $39.51 \mathrm{a}$ & $74 \mathrm{a}$ \\
\hline Glomus sp D32 & $26.30 \mathrm{~b}$ & $4.33 \mathrm{ab}$ & $28 \mathrm{ab}$ & $35.23 \mathrm{~b}$ & $68 \mathrm{~b}$ \\
\hline Gigaspora sp & $16.43 \mathrm{bc}$ & $4.16 \mathrm{ab}$ & $27 \mathrm{a} \mathrm{b}$ & $11.34 \mathrm{c}$ & $63 \mathrm{~b}$ \\
\hline
\end{tabular}

- Values followed the same letter are not significantly different $(\rho<0.05)$.

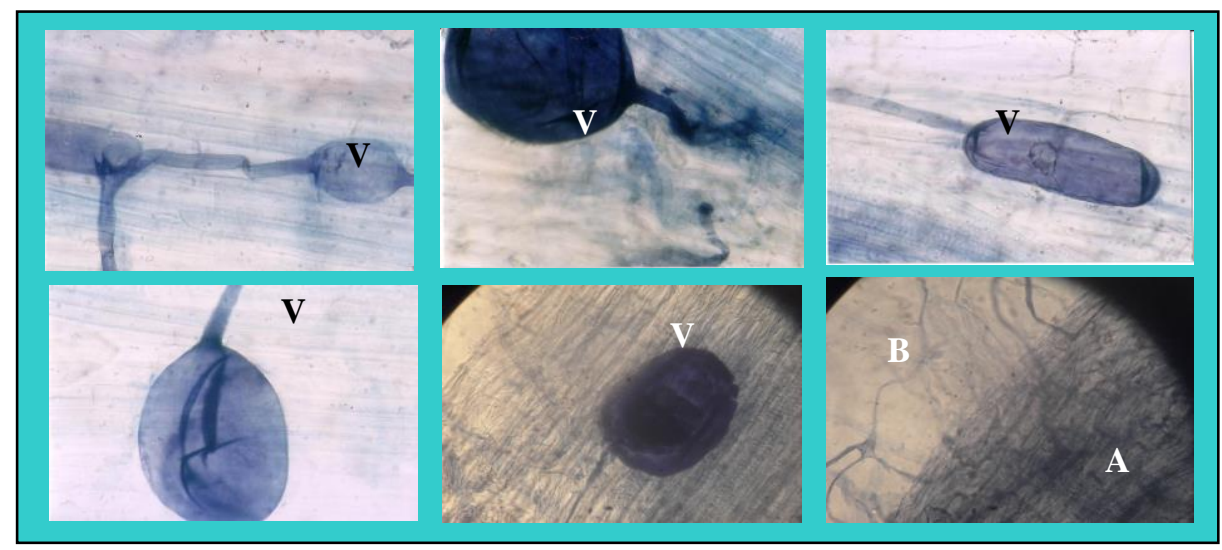

Figure 2. Vesicular (V), intraradical hyphae (A), and extraradical hyphae in root (B).

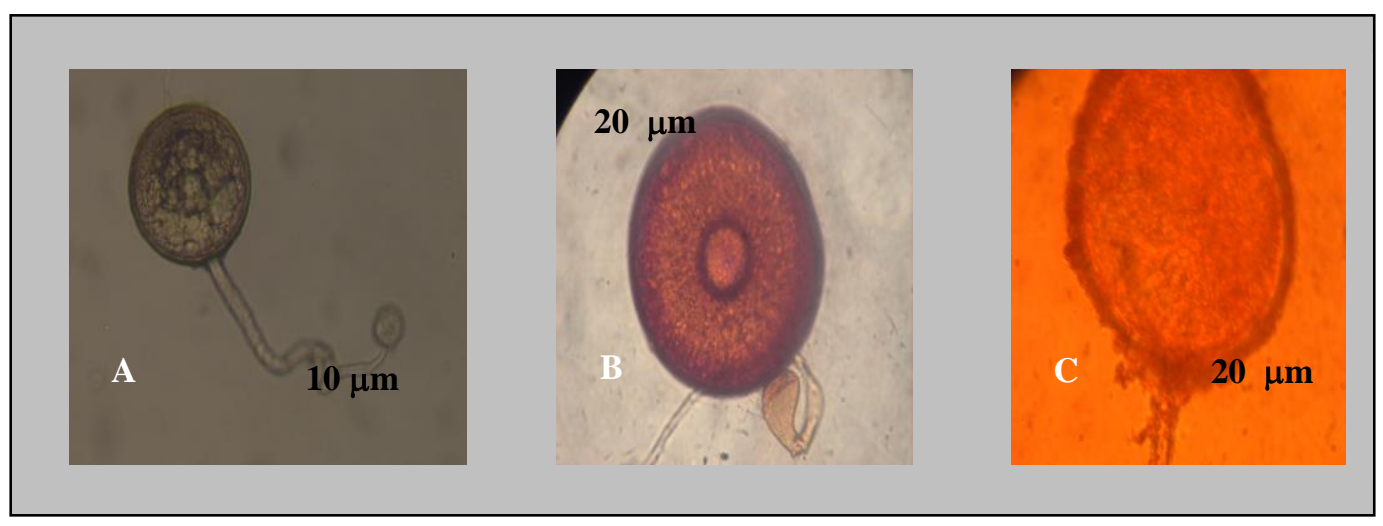

Figure 3. Spores of Glomus sp (A), Color: a continuum from white to yellow-brown, Shape: globose, Spore wall: three layers. Gigaspora sp (B), Color: yellow-brown, Shape: Globose to subglobuse, Spore wall: consisting of three layers. and Acaulospora sp (C), Color: orange-brown, Shape: globuse, Spore wall: Three layers. 
In the nursery conditions, Glomus $\mathrm{sp}$ TD15, Glomus sp D32, and Gigaspora sp, formed AMF in Combretocarpus rotundatus Miq seedlings (Table 2). AMF colonization was higher than $60 \%$ in all inoculated seedlings. There was a significant difference between three AMF species and control seedlings. AMF colonization was higher in seedlings colonized by Glomus sp TD15 than with the other AM fungi species. AM fungi colonization of $C$. rotundatus using spores of Glomus sp TD15, Glomus sp D32, and Gigaspora sp increased plant height, stem diameter (Fig. 4, and 5).

Even though the AM fungi of trees in peat swamp forest has been reported (Tawaraya et al., 2003), the role of AM fungi in species originating from peat swamp forest needs to be clarified. This result demonstrate for the first time that AM fungi have positive effects on Combretocarpus rotundatus Miq after five months under nursery conditions. Colonization by three AMF species was identified as the most appropriate fungi for improving early growth of Combretocarpus rotundatus Miq after five months under greenhouse nursery conditions. Therefore, Glomus sp TD 15 is to be AMF candidate for production of C. rotundatus under nursery conditions. Similar result has also been reported by Morte et al., (2008) inoculation with Glomus mosseae significantly increased the growth of Phoenix canariensis. The positive effect of Glomus sp colonization on Canary palm has also been observed under different growth condition (Morte and Honrubia, 2002) and in other palms like Bactris gasipaes. Smith and Read, 2008) concluded that, the arbuscular mycorrhizal fungi supply nutrients to their host plant, especially phosphorus. The fungi absorb phosphate from the soil through their extraradical hyphae and incorporate it into the cytosolic pool, while the excess of phosphorus $(\mathrm{P})$ is transferred to the vacuoles and translocated to the intraradical hyphae (Saito, 2000). The forms of $P$ involved in long distance transport along the hyphae are probably inorganic orthophosphate $(\mathrm{Pi})$, poly-phosphate and organic phosphate such as Phosphate-ester (Ezawa et al., 2002). Ecological categories of AMF may be more useful for summarizing fungal performance in the nursery conditions (Brundrett et al., 2005).
The AM fungi expand their filaments in soil and plant roots. This filamentous network promotes bi-directional nutrient movement where soil nutrients and water move to the plant and plant photosynthates flow to the fungal network. The structures produced by fungi are intraradical and extraradical spores, intraradical hyphae, and extraradical hyphae. Intraradical AM fungal mycelium form a network around and inside cortical cells of plant roots, extraradical AMF mycelium can spread throughout the soil surrounding the root system and increase the ability to explore soil areas, accessing water and nutrients for plant roots. Benefits to plants are improved water and nutrient uptake, enhanced $\mathrm{P}$ transport, and drought and disease resistance (Dalpe, 2004).

Survival rates of seedlings are important for the first establishment of plant growth of Combretocarpus rotundatus. The ability of AM fungi to increase crop growth and yield, attributed to better nutrition in phosphorus-poor and phosphorus-fixing soils, have been reported for hundreds of plants species (Auge and Moore, 2005). Mycorrhizal symbiosis can also improve host responses to other environmental limitations, such as drought (Brundrett et al., 1996; Alguacil et al., 2006; Aliasgharzad et al., 2006; Aroca et al., 2007), salinity (Auge, 2004; Gupta and Rautaray, 2005; Cho et al., 2006).

In conclusion, colonization by Glomus sp TD15 consistently increased the growth of five months old Combretocarpus rotundatus seedlings. Glomus sp TD15 could, therefore, be used to inoculate Combretocarpus rotundatus $\mathrm{Miq}$ in nurseries because this fungi was well adapted to the environmental conditions and had a superior effect on plant growth as compared with the other AMF types. Indigenous AM fungi are suggested to be potentially good inoculants for native peat swamp tree species under greenhouse nursery conditions and would be beneficial for the restoration of degraded peat swamp forest.

This study may also contribute to the future application of AM fungi to restoration of peatlands. Our finding that "generalists" can colonize host plants over a low of $\mathrm{pH}$ values is novel, and it is expected that these fungi may have a great potential as "niversal fungi" for environmental restoration if they can be isolated successfully. 


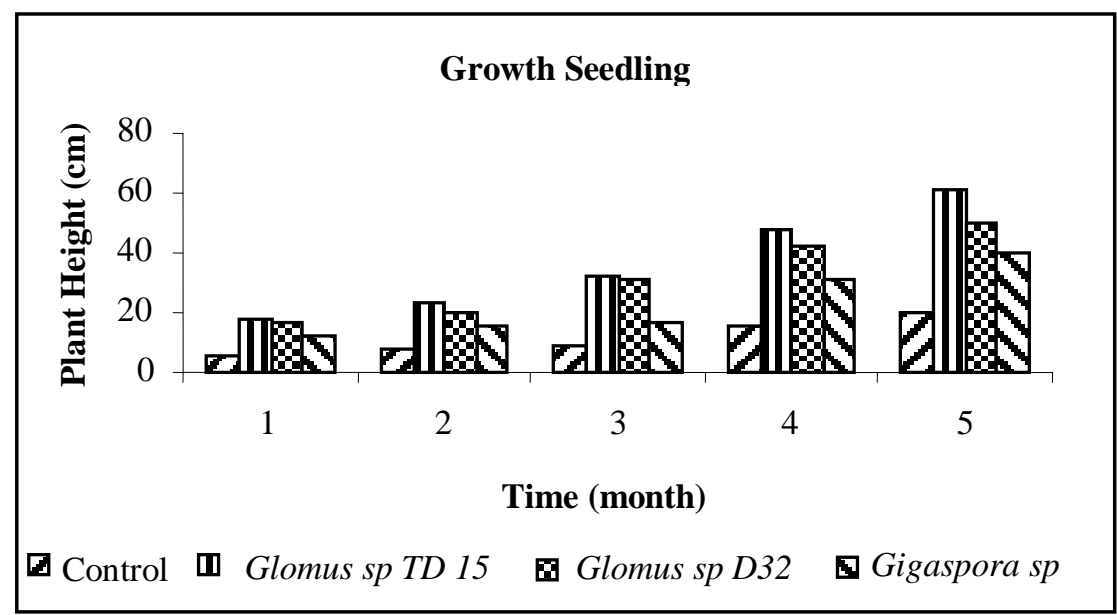

Figure 4. Height increase with time of Combretocarpus rotundatus plants inoculated with three AMF types.

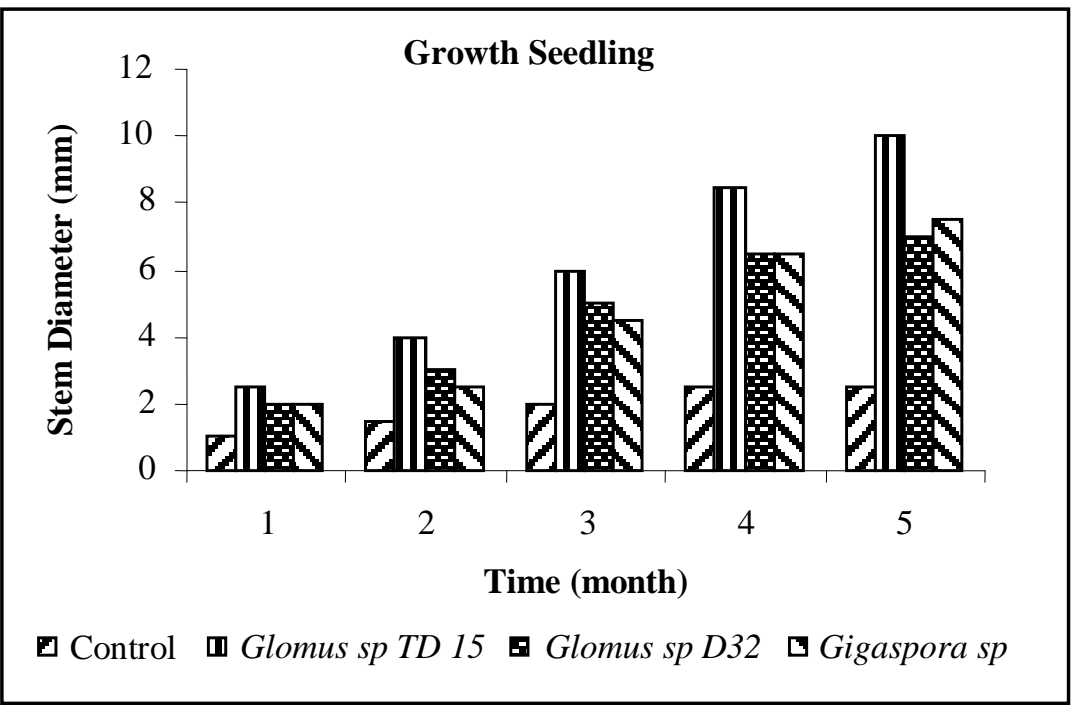

Figure 5. Stem diameter increase with time of Combretocarpus rotundatus plants inoculated with three AMF types.

\section{Acknowledgements}

This study was financially supported by a RESTROPEAT project, 2005.

\section{References}

Alguacil, M., Caravaca, F., Diaz-Vivancos, P., Hernandez, J.A. and Roldan, A. 2006. Effect of Arbuscular Mycorrhizae and Induced Drought Stress on Antioxidant Enzyme and Nitrate Reductase Activities in Juniperus oxycedrus L. Grown in a Composted Sewage Sludge Amended Semi Arid Soil. Plant and Soil, 279: 209-218.
Aliasgharzad, N., Neyshabouri, M.R. and Salimi, G. 2006. Effects of Arbuscular Mycorrhizal Fungi and Bradyrhizobium Japonicum on Drought Stress of Soybean. Biologia, 61: S324-328 Suppl.19.

Amaya-Carpio, L., Davies, F.T.Fox. and He, T.C. 2009. Arbuscular Mycorrhizal Fungi and Organic Fertilizar Influence Photosynthesis, Root Phosphatase Activity, Nutrition, and Growth of Ipomoea carnea ssp fistulosa. J. from Photosyntheta, 47: 1-10

Aroca, R., Porcel, R. and Rutz-Lozano, J.M. 2007. How does Arbuscular Mycorrhizal Symbiosis Regulate Root Hydraulic Properties and Plasma Membrane Aquaporins in Phaseolus Vulgaris Under Drought, Cold or Salinity Stresses?. New Phytologist, 173: 806-816. 
Auge', R.M. 2001. Water Relations, Drought and VesicularArbuscular Mycorrhizal Symbiosis. Mycorrhiza, 11: 3-42.

Auge', R.M. 2004. Arbuscular Mycorrhizae and Soil/Plant Water Relations. Canadian J. of Soil Science, 84: 373-361.

Auge', R.M. and Moore, J.L. 2005. Arbuscular Mycorrhizal Symbiosis and Plant Drought Resistance. In book Mycorrhizal Role and Applications. Ed, VS Mchretra, p: 136-162.

Bucher, M. 2007. Functional Biology of Plant Phosphate Uptake at Root and Mycorrhiza Interfaces. $J$. from New Phytologist, 173: 11-26.

Brundrett, N.N., Bougher, B., Dell, T., Grove and Malajczuk, N. 1996. Working with Mycorrhiza in Forestry and Agriculture. ACIAR Monograph. 32.374+xp.

Brundrett, M., Malajczuk, N., Mingqin, G., Daping, X., Knelling, S. and Dell, B. 2005. Nursery Inoculation of Eucalyptus Seedlings in Western Australia and Sothern China using Spore and Mycelial Inoculum of Diverse Ectomycorrhizal Fungi from Different Climatic Regions. J. from Forest Ecology and Management, 209: 193-205.

Cardoso, I.M. and Kuyper, T.W. 2006. Mycorrhizas and Tropical Soil Fertility. Agric. Ecosyst. Environ. 116: $72-84$

Cheyne, S., Thompson, C., Phillips, A., Hill, R. and Limin, S. 2007. Density and Population Estimates of Gibbons (Hylobates agilis albibarbis) in the Sebangau Catchment, Central Kalimantan, Indonesia. Primates, 49: 50-56.

Cho, K., Toler, H.D., Lee, J., Ownley, B.H., Jean, C., Stutz, J.C., Moore, J.L. and Auge, R.M. 2006. Mycorrhizal Symbiosis and Response of Sorghum Plants to Combined Drought and Salinity Stresses. J. of Plant Physiology, 163: 517-528.

Dalpe, Y. 2004. Arbuscular Mycorrhiza Inoculum to Support Sustainable Cropping System. Online, Crop Management doi: 10.1094/CM-20040301-09-RV.

Dell, B. 2002. Role of Mycorrhizal Fungi in Ecosystems. CMV J, 1: 47-60.

Ezawa, T., Smith, S.E. and Smith, F.A. 2002. Pmethabolism and Transport in AMF. In: Smith, S.E., Smith, F.A. (Eds). Diversity and Integration in Mycorrhizas. Pp: 221-230. Kluwer Academic Publishers, Dordrecht, the Netherlands.

Gai, J.P., Christie, P. and Feng, G. XL.Li. 2006. Twenty Years of Research on Community Composition and Species Distribution of Arbuscular Mycorrhizal Fungi in China. Mycorrhiza, 16: 229-239.
Gorham, E. 1991. Northern Peatlands: Role in the Carboncycle and Probable Responses to Climatic Warming. Ecological Applications, 1: 182-195.

Gupta, N. and Rautaray, S. 2005. Growth and Development of AM Fungi and Maize under Salt and Acid Stress. Acta Agriculture Scandinavica Section B-Soil and Plant Sciencs, 55 (2): 151-157.

Immirizi, C.P. and Maltby, E. 1992. The Global Status of Peatlands and their Role in the Carbon Cycle. Wetlads Ecosystems Research Group, Report 11. Exeter, UK: University of Exeter.

Jaenicke, J. and Siegert, F. 2008. Monitoring Restoration Measures in Tropical Peatands using Radar Satellite Imagery. Dalam Proceedings of the $13^{\text {th }}$ International Peat Congress: After Wise Use-The Future of Peatlands. Volume 1. Edited by Catherine $\mathrm{F}$ and John Feehan. Tullamore, Ireland. Hal: 212-214.

Kiers, E.T., Lovelock, C.E., Krueger, E.L. and Herre, E.A. 2000. Differential Effects of Tropical Arbuscular Mycorrhizal Fungal Innocula on Root Colonization and Tree Seedling Growth: Implications for Tropical Forest Diversiy.

Liu, A., Plenchette, C. and Hamel, C. 2007. Soil Nutrient and Water Providers: How Arbuscular Mycorrhizal Mycelia Support Plant Performance in a Resourcelimited World. In: Hamel, C., Plenchette, C. (Eds.). Mycorrhizae in Crop Production. Pp. 37-66. Haworth Food \& Agricultural Products Press. Binghamton, NY.

Lovelock, C.E. and Ewel, J.J. 2005. Links Between Tree Species, Symbiotic Fungal Diversity and Ecosystem Functioning in Simplified Tropical Ecosystem. New Phytologist, 167: 219-228.

Marschner, H. and Dell, B. 1994. Nutrient Uptake in Mycorrhizal Symbiosis. Plant Soil, 159: 89102.

Miller, R.M. and Jastrow, J.D. 2000. Mycorrhizal Fungi Influence Soil Structure. In: Kapulnik, Y., Douds, Jr., D.D. (Eds.). Arbuscular Mycorrhizas: Physiology and Function. Pp. 318. Kluwer Academic Publishers, Dordrecht, Netherlands.

Morte, A., Beatriz, D., Manuela, P.G., Olmos, E. and Honrubia, M. 2008. Ultrastructural Localization of Acid Phosphatase in Arbusculate Coils of Mycorrhizal Phoenix canariensis Roots. J. of Physiologia Plantarum, 132: 503-513.

Morte, A. and Honrubia, M. 2002. Growth Response of Phoenix canariensis to Inoculation with Arbuscular Mycorrhizal Fungi. J. of Palms, 46: 76-80. 
Opik, M., Moora, M., Liira, J. and Zobel, M. 2006. Composition of Root-colonizing Arbuscular Mycorrhizal Fungal Communities in Different Ecosystems Around the Globe. J. Ecol, 94: 778790 .

Page, S.E., Siegert, F., Rieley, J.O., Boehm, H.D.V., Adi, J. and Limin, S. 2002. The Amount of Carbon Released from Peat and Forest Fires in Indonesia in 1997. Nature, 420: 61-65.

Page, S.E., Graham, L.L.B., Hoscilo, A. and Limin, S. 2008. Vegetation Restoration on Degraded Tropical Peatlands: Opportunities and Barriers. Paper Presented and Submitted to International Peatland Symposium, June 2008, Tullamore, Ireland.

Picone, C. 2003. Managing Mycorrhizae for Sustainable Agriculture in the Tropics. In: Vandermeer, J.H. (Ed.). Tropical Agroecosystems. Pp. 95-132. CRC Press, Boca Raton, FL.

Radjagukguk, B. 2001. Sustainable Agriculture on Tropical Peatlands. International J. for the Management of Tropical peatlands, 1 (1): 24-26.

Rillig, M.C. 2004. Arbuscular Mycorrhizae, Glomalin, and Soil Aggregation. Can. J. Soil Sci, 84: 355-363.

Saito, M. 2000. Symbiotic Exchange of Nutrients in Arbuscular Mycorrhizas: Transport and Transfer of Phosphorus. In: Kapulnik, Y., Douds, D.Jr (Eds). Arbuscular Mycorrhizas: Physiology and Function. Pp: 85-106. Kluwer Academic Publishers, Dordrecht, the Netherlands.

Saito, M., Shibuya, M., Sehat, J., Takahashi, K., Jamal, Y., Segah, H., Patricia, E.P. and Limin, S.H. 2002. Preliminary Selection of Fast-growing Tree Species with Tolerance to an Open and Dry Tropical Peat Land in Central Kalimantan: To Develop a Preceding Planting Method. Dalam Proceedings of the International Symposium on Land Management and Biodiversity in Southeast Asia. Organized by Hokkaido Univ Sapporo and Research Centre for Biology. Bogor, Indonesia: 75-79.

Shimada, S. 2001. Distribution of Carbon in Peat Layer and Estimation of Carbon Mass using Satellite Data in a Tropical Peatland, Central Kalimantan, Indonesia. Ph.D thesis, Hokkaido University.

Shimada, S., Takahashi, H., Haraguchi, A., Kaneko, M. 2001. The Carbon Content Characteristics of Tropical Peat in Central Kalimantan, Indonesia: Estimating their Spatial Variability in Density. Biogeochemistry, 53: 249-267.

Smith, V. 2002. Investigation Into the Human Communities of the Sebangau Peat Swamp Forest, Central Kalimantan, Indonesia: Demography, attitudes and impacts. Report submitted to Oxford Brookes University.
Smith, S.E. and Read, D.J. 2008. Mycorrhizal Symbiosis. Trird edition. Academic Press. New York.

St-Arnaud, M. and Vujanovic, V. 2007. Effects of the Arbuscular Mycorrhizal Symbiosis on Plant Diseases and Pests. In: Hamel, C., Plenchette, C. (Eds.). Mycorrhizae in Crop Production. Pp. 67-122. Haworth Food \& Agricultural Products Press. Binghamton, NY.

Tawaraya, K., Takaya, Y., Turjaman, M., Tuah, S.J., Limin, S.H., Tamai, Y., Cha, J.Y., Wagatsuma, T. and Osaki, M. 2003. Arbuscular Mycorrhizal Colonization of Tree Species Grown in Peat Swamp Forest of Central Kalimantan, Indonesia. J. of ecology and management, 182: 381-386.

Turjaman, M., Tamai, Y., Sagah, H., Limin, S.H., Cha, J.Y., Osaki, M. and Tawaraya, K. 2005. Inoculation with the Ectomycorrhizal Fungi Pisolithus arhizus and Scleroderma sp. Improves Early Growth of Shorea pinanga Nursery Seedlings. New forests, 30: 67-73.

Turjaman, M., Tamai, Y., Sagah, H., Santoso, E., Osaki, M. and Tawaraya, K. 2006. Arbuscular Mycorrhizal Fungi Increased Early Growth of Two Nontimber Forest Product Species Dyera polyphylla, and Aquilaria filarial under Greenhouse Conditions. Mycorrhiza, 16: 459464.

Wosten, J.H.M., van der Berg, J., van Wijk, P., Gevers, G. J.M., Giesen, W.B.J.T., Hooijer, A., Idris, L.P.H., Rais, D.S., Siderius, C., Silvius, M.J., Suryadiputra, N. and Wibisono, I.T. 2006. Interrelationships Between Hydrology and Ecology in Fire Degraded Tropical Peat Swamp Forest. Water Resources Development, 22: 157174.

Wright, S.F. 2005. Management of Arbuscular Mycorrhizal Fungi. In: Zobel, R.W., Wright, S.F. (Eds.). Roots and Soil Management: Interactions between Roots and the Soil. Pp. 183-197. American Society of Agronomy. Crop Science Society of America, Soil Science Society of America, Madison, WI.

Yulianto, E., Hirakawa, K. and Tsuji, H. 2004. Charcoal and Organic Geochemical Properties as an Evidence of Holocene Fire in Tropical Peatland, Central Kalimantan, Indonesia. Tropics, 14: 5563. 